Full reference: McLaughlin, C., Elamer, A., Glen, T., AlHares, A., \& Gaber, H.R. (2019) 'Accounting society's acceptability of carbon taxes: Expectations and reality', Energy Policy, Forthcoming (Accepted $5^{\text {th }}$ May 2019).

\title{
Accounting society's acceptability of carbon taxes: Expectations and reality
}

\section{Craig McLaughlin}

Strathclyde Business School, University of Strathclyde, Glasgow, G1 1XQ, Scotland

Email: craig.mclaughlin.100@strath.ac.uk

\begin{abstract}
Ahmed A. Elamer *
Brunel Business School, Brunel University London, Kingston Lane, Uxbridge, London, UB8 3PH $\mathrm{UK}$; and

Department of Accounting, Faculty of Commerce, Mansoura University, Mansoura, Egypt Email: ahmed.a.elamer@gmail.com

*Corresponding author

\section{Thomas Glen}

School of Business and Enterprise, University of the West of Scotland, Paisley, PA1 2BE, UK Email: thomasglen15@gmail.com

\section{Aws AlHares}

Department of Accountancy and Finance, Business School, University of Huddersfield, UK, and Faculty of School of Business Studies, College of the North Atlantic in Qatar, Qatar Email: aalhares@yahoo.co.uk
\end{abstract}

\section{Hazem Rasheed Gaber}

Arab Academy for Science, Technology and Maritime Transport, Alexandria, Egypt Email: hazem.rasheed@aast.edu 


\title{
Accounting society's acceptability of carbon taxes: Expectations and reality
}

\begin{abstract}
This article seeks to examine accountants' perceptions of carbon taxes in addressing climate change. Specifically, it aims at (i) a better understanding of accountants opinions on carbon taxes; (ii) how energy companies have adapted their business operations since introducing carbon tax. The article's primary sources of data are (1) a 2018 survey distributed to 45 accounting professionals in Scotland, which specialise in energy finance and a formal interview with a regional finance director of a multinational energy company. The results show how the accountants are in favour the carbon tax due to its positive environmental impact, however, do not agree with the associated rising utility costs. Though, carbon tax, from an energy business' perspective, is viewed negatively due to its effects on the end users of energy. This study contributes to the current research by demonstrating the role of accounting society in boosting public awareness of climate change. The findings of this study will help regulators and policy makers in the UK to evaluate the adequacy of current carbon tax reforms and to promote the public awareness of climate change to reduce carbon emissions.
\end{abstract}

Keywords: Carbon Emissions, Carbon Tax, Climate Change, Energy Companies, Environmental Tax 


\section{Introduction}

'Environmental taxes sent messages which permeate throughout the economy, encouraging a wide range of appropriate responses: changing production methods; switching to less polluting inputs; and reducing demand for goods which have significant negative impacts throughout all stages of production. Taxes also ensure that different people are exposed to the same price signal, leading to more cost-effective ways of achieving a given environmental goal.'(ESRC, 2000, p.2).

Across the globe, world governments are working towards tackling the issues surrounding climate change by imposing taxes, amongst other things, on carbon dioxide emissions (Adhikariparajul et al., 2019; Elmagrhi et al., 2019; Alshbili et al., 2019; Evangelinos et al., 2015; Eweje, 2011; Gerged et al., 2018; Hansford et al., 2004). The principle idea being that they would encourage the worst offenders in society- energy companies- to be more aware of their carbon footprint and thus find ways to lower the amount of carbon dioxide they expel into the atmosphere. Environmental issues are of massive importance globally just now as seen through various world conferences held on the matter, such as the Paris agreement in 2015 which was signed by representatives from 192 different countries (Chen \& Montes-Sancho., 2017; Hansford et al., 2004; Li \& Lin, 2016). Many of the issues surrounding the environment are brought on by humans and their contributions to how we live our lives, from driving our cars to powering our homes, it all has a lasting impact on the planet and so carbon taxes are a way of paying for the damage we cause (Guo et al., 2014). However, the success of these taxation regulations require appropriate knowledge to determine the effects of carbon taxes on climate change (Hwang \& Kim, 2017; Martin \& Rice, 2014). Also, the complex nature of tax regulations make the perceptions of such regulations challenging for both companies and public accountants.

This study aims to contribute to this debate by examining the Scottish accounting society's perceptions of carbon taxes in addressing climate change. This research addresses the 
need for the development and awareness regarding carbon tax. Specifically, it aims at (i) obtain a deeper understanding of accountants opinions on carbon taxes when presented with information on how carbon taxes could affect environment; and (ii) how energy companies have adapted their business operations since announcement of the newly formed carbon tax. Carbon taxes, in theory, work by imposing a direct tax on emissions produced from burning fossil fuels, for example coal, which is then paid for by the polluter (Zhang et al., 2017). Often, companies will pay this expense by increasing the cost of gas and electricity for consumers, therefore the carbon tax ends up being paid for by energy customers rather than the energy provider. These problems that are associated with a carbon tax provide reasons for further study into the implications that carbon tax can have and whether they are considered to be a good idea by the public, if they are even aware of their existence.

Other areas affected by imposing the carbon tax focussed around their impact on an energy producing business. Due to the high expense incurred from a carbon tax, energy companies are affected in various ways which has resulted in them having to alter business operations to lower the tax bills or pass on the charge. One way in which this is achieved is through generating more of their energy for customers through renewable energy sources such as wind farms which do not produce any carbon emissions. The tax on carbon emissions has led to the gradual demise of coal power which is a very heavy carbon pollutant. Coal was the dominant fuel source within the UK until recently, in $201340 \%$ of electricity in the UK was coming from coal fired powered stations, however a change in carbon tax and energy production led to the closure of many coal fired power facilities meaning coal now accounts for less than $10 \%$ of electricity needs. These effects led to a further research need by setting out to gain a professional opinion from those who work within the energy sector and allowed to ask the question How does a carbon tax affect how an energy business operates? 
Most recently, the literature has considered the impact and influence of carbon taxes on the environment. A growing number of qualitative and quantitative studies have clearly demonstrated the public's preference for low-carbon grants in excess of taxes (Cherry et al., 2012; de Groot \& Schuitema, 2012; Kallbekken \& Aasen, 2010; Schleich et al., 2018). A USA survey found that the majority of Americans (i.e., 71\%) support tax repayments and discounts for eco-friendly cars or solar panels, less than $50 \%$ support the introduction of carbon taxes (Maibach et al., 2015). Moreover, there is mixed evidence on regulation and/or the level of carbon taxes (Cherry et al., 2012; Clinch \& Beuermann, 2006).

Another strand of literature suggest that public resistance against climate change policies was a fundamental obstacle which has hindered the implementation of climate change policy and regulation, such as introduction of personal carbon allowances (Crowley, 2017; Drews \& van den Bergh, 2016; Harrison, 2010; Harrison \& Peet, 2012; Jagers et al., 2019; Rabe \& Borick, 2012). In USA, (Shwom et al., 2010) assert that public acceptability is important for encouraging policy-makers to consider appropriate climate actions.

On the other hand, most of empirical studies are likely to capitalise on the favourable ecological influences and therefore the carbon taxes' effectiveness does not appear to be constantly recognised by the wide-ranging public. Some studies found that the majority people consider carbon taxes as a pretext to increase monetary revenues, when tax revenues are assigned for non- ecological purposes. Another strand of research (Baranzini \& Carattini, 2017; Carattini et al., 2019; Kallbekken \& Sælen, 2011; Sælen \& Kallbekken, 2011) found a negative relation between perceived ecological ineffectiveness and identified support for carbon taxes. The last strand of the literature found that ecological taxes are perceived by the majority of the general public as "penalties", i.e. coercive actions enforcing a behaviour change (Brannlund \& Persson, 2012; Kallbekken \& Sælen, 2011). 
This study advances the ongoing debate on the public acceptability of carbon taxes by employing survey data and an interview to examine the accountants' perceptions of carbon taxes in addressing climate change. Firstly, the accountants view provides a unique and underexplored data set to be examined, due to their active involvement in tax policy and assumed understanding. Secondly, we confirm that increase consumer prices of gas and electric bills is one of the main barriers to the carbon taxes acceptability. Thirdly, by combining all the research and obtaining a more detailed understanding of the public opinions from professionals, the overall effectiveness of a carbon tax could be questioned. Finally, by gaining the relative data conclusions can be made to understand are carbon taxes effective in mitigating climate change?

To address the research objectives, a survey targeted at professional accountants was created and distributed to accountants in Scotland as the opinions of professionals produce a higher standard of reliable data. Aside from distributing a survey, there was a face to face interview conducted with a regional finance director of a large energy supplier. The purpose of using multiple data collection methods and targeting a specific demographic was to yield more reliable results that could be critically analysed. Once all the relevant data was critically analysed, recurring themes were highlighted and discussed to form the basis of the conclusions. Thus, this paper aims to develop our theoretical and empirical understanding of how accountancy practitioners accept and/or support the carbon taxes.

The remainder of this paper is structured as follows. Section 2 contains the background information, followed by Section 3, the literature review which encompass previous studies on carbon taxes, followed by the methodology section which discusses how the study was carried out and what methods of research were used. Section 5 presents the findings of the research 
and what they mean in relation to the current literature. In the final section, conclusions are drawn and avenues for future research are presented.

\section{Background}

Climate change is one of the biggest political talking points in the world today. Tackling climate change will take a collective effort from countries across the globe. From a climate policy standpoint, the Scotland context is of particular interest. In 2009, the Scottish Parliament accepted an aspiring climate change regulation. Specifically, the climate change (Scotland) Act 2009 agreed the aim of a $42 \%$ emissions reduction by 2020 and an $80 \%$ emissions reduction by 2050 (CCP, 2018). Also, Scotland is prominent the way in the shift to a low carbon society. Up-to-date data on Scotland's performance from the 2015 Greenhouse Gas Inventory demonstrate that Scotland's actual emissions, including those from aviation and shipping decreased by $3 \%$ between 2014 and 2015, and were 38\% below 1990 emissions, compared with a fall of $35 \%$ for the UK as a whole (CCP, 2018). More importantly, the latest UK Government data indicates that the equivalent of 54\% of Scotland's gross electricity consumption came from renewable sources in 2016 , compared to $12.2 \%$ in 2000 , ensuring that Scotland on the way to achieving targets of generating $100 \%$ of electricity demand from renewables by 2020 and $50 \%$ of all energy for Scotland's heat, transport and electricity consumption from renewables by 2030. Also, Scotland's manufacturing and industry sector saw emissions fall by $49 \%$ between 1990 and 2015 . Finally and through sustained efficiency improvements in farming and better fertiliser management, Scotland have reduced emissions in the agriculture sector by 3.8 MTCO2e (25.8\%) between 1990 and 2015 (CCP, 2018).

There are a number of methods that policy makers use to decrease environmentally harmful activities (e.g., carbon emissions) such as regulations, voluntary agreements, and taxation (Hansford et al., 2004). One such effort has been the introduction of environmental 
taxes which are a form of fiscal policy, fiscal policy being "the use of government spending and taxation to influence the economy" (Horton and El-Ganainy, 2009, p52), that serve as a means to help countries lower their carbon footprint thus slowing down, or better yet, improving the effects of climate change. Such taxes have been implemented globally including within the UK. Environmental taxes are taxes, which are linked to environmental objectives; encourages positive environmental behaviour; and tax structure directly relates to environmental objectives (Smith, 2012). For example, higher pollution leads to a greater taxes becoming due (Hansford et al., 2004).

These taxes come to the UK in various forms such as; The climate change levy, Aggregates Levy, Landfill Tax, EU emissions trading scheme (ETS), Carbon reduction commitment energy efficiency scheme and carbon price support (Hansford et al., 2004; Smith, 2012). This study will focus on the Carbon Tax, or carbon price floor which falls under the 'Carbon price support', and its profound effect on business' and ultimately consumers while also, briefly mentioning how the Carbon Tax compares with the ETS as they can be closely tied together.

The 'carbon price floor', more commonly known as the carbon tax, was introduced to the UK in 2013. With the carbon tax, power plants that use fossil fuels being charged depending on their carbon emissions (Gosden, 2016). These taxes can be traced back to 80 years ago to something known as Pigouvian taxes. Pigou (1920), taught us that the optimal tax to address a negative environmental externality is equal to the marginal external damage from the polluting activity (Jacobs and de Mooij 2015). However, "there is little experience with the design of these taxes and almost none with a Pigouvian tax that covers a substantial portion of the economy, as would a carbon tax" (Metcalf and Weisbach, 2009). Carbon taxes do provide additional revenue for the government, which varies from country to country, such directly 
affects its environmental effectiveness and can have socio-economic impacts through reinvestment in certain areas (Wang et al., 2016).

The reasoning behind installing such a tax as the carbon tax is to ensure as a nation we can try to move towards the internalisation of the costs associated with the emissions of carbon dioxide (CO2) from burning fossil fuels (Böttcher \& Müller, 2015; Ekins, 1994). Emissions caused by these greenhouse gases (GHG) are considered by most scientists to enhance the greenhouse effect and are therefore likely to lead to a consequential increase in the earths average surface temperature in this current century and thereafter (Ekins, 1994). CO2 was chosen specifically over other GHG to be taxed because Carbon dioxide is the most abundant and longest lived GHG, lasting for over 100 years once emitted into the atmosphere (Hsu, 2011).

However, there is an argument against the case that carbon taxes only apply to $\mathrm{CO} 2$ by saying they are not solely for taxing $\mathrm{CO} 2$, they also apply to other GHG such as methane, nitrous oxide and perfluorocarbons from aluminium smelting (Robson, 2014). Carbon taxes are a frequently discussed economic instrument for carbon emission reduction and prevention of global climate change (Wang et al., 2016). Carbon policies like carbon taxes on GHG provide incentives to increase energy efficiency and resource productivity which will, in-turn, give UK producers a long-term competitive advantage worldwide, where fossil fuel prices could rise due to their scarcity and carbon reduction policies (Murray, 2016).

The UK also imposed a climate tax known as the climate change levy (CCL) in 2001 (Metcalf and Weisbach, 2009). However, many do not consider this to be carbon tax, rather "it was used for the non-residential final consumption of electricity, natural gas, and solid fuels. Rates are set according to each fuel but do not necessarily correspond to carbon content and have changed over time. We therefore do not consider it a carbon tax." (Carl and Fedor, 2016). 
Also, ETS schemes are used as an alternative to directly taxing carbon. In January 2005, the European Union (EU) Emissions trading scheme (ETS) was introduced as part of an agreement to cut worldwide CO2 emissions (Bredin and Muckley 2011; Murray \& Rivers., 2015). However, the ETS in the EU only covers a small portion of GHG emissions (Metcalf and Weisbach, 2009) per the European commission website those include CO2, nitrous oxide (N2O) and Perfluorocarbon (PFC's).

Emissions trading involves issuing- usually from the government- emissions permits or allowances to cover the desired quantity of emissions, and their transfer, by sale or otherwise, to emitters (Andersen and Ekins, 2009). They are designed in such a way so that firms who chose to pollute more than the allowances they initially received must purchase extra allowances in the open market from firms that have used less than their allocated allowance (Breedin and Muckley 2011).

Although both ETS and Carbon taxes are thought to be equivalent and efficient in lowering emissions, a carbon tax in practice is simpler, faster to implement and more transparent (Cuevas and Haines, 2016).

\section{Literature Review}

\subsection{Carbon Tax - Effect on consumers}

A major obstacle with carbon taxes is that the burden will fall more heavily on the poor. With differences in income, living conditions, consumption preferences and patterns, different socio-economic groups react differently to the same stimuli. Low-income people tend often spend a larger portion of their income on energy-intensive products to meet their basic needs (heating, electricity) and lack any options to substitute (Wang et al., 2016). Literature shows conflicting views on the costs a carbon tax would bring to consumers. Uncertainties can lead 
to widespread rejection from the public, however a study by the London school of economics revealed that a modest tax of $£ 20$ a tonne would have a negligible impact on consumer prices (Murray, 2016).

Recent research has suggested that behavioural economic theory be considered as part of understanding of carbon taxes acceptability. In general, behavioural economics theory advances the significant question of whether remedial environmental taxation should be supplemented by further instruments that target behavioural unfairness. For instance, many studies having estimated the distributional impact within households from multiple perspectives, however these studies have focused on developed nations and conclude that carbon taxes tend to be regressive (Wang et al., 2016). A further study could be carried out in developing nations where a carbon tax would likely have a much more negative impact on households.

For households, carbon mitigation activities can improve the environment quality and mitigate the adverse impact of climate change thus can bring long-term environmental benefits to human beings (Wang et al., 2016).

\section{Carbon tax - effect on business}

Taxing carbon poses major issues for GHG emitters; it will affect overall profitability, can lead to job losses due to fossil fuel requirements becoming obsolete thus requiring less workforce and commodities dropping in price as they have no further use in a country, for example, coal in the UK. As recently as 2013 coal was the dominant fuel in powering the UK electricity needs, generating more than $40 \%$ of all electricity (Webster, 2014). By 2015 that number had dropped to 22\%; between April and June of 2016 coal fell to its lowest ever record 
of $6 \%$. While some coal plants have been shut under EU rules, those that remain are struggling, due, to one of the UK's most divisive energy policies: the carbon tax (Gosden, 2016).

One company which has felt the effects of the carbon tax all too well is Scottish Power. In 2015 Scottish Power's traditional energy business improved their operating profits by $3.3 \%$ increasing to $£ 203$ million during the first half of the year, however they faced a carbon tax bill of $£ 150$ million (Herald, 2015). The tax bill has led to the closing of Scotland's largest operational coal power plants, Longannet power station, with (Dickie, 2015) claiming that "high carbon taxes and transmission charges mean it is no longer economic to generate electricity from coal or gas in Scotland". The director-general of the confederation of UK coal producers points out that in the government's efforts to cut emissions, has resulted in a significant increase in the cost of coal, with a tonne of coal costing $£ 37$ and the tax being $£ 50$ (Bounds, 2015). This will be further explored in during the research section on how an energy business is dealing with issues surrounding carbon tax by interviewing a regional finance director of such a business for his professional opinion and how it compares with literature surrounding the issues of carbon tax.

Nonetheless, not all firms have a negative opinion of these taxes. On one side, industrial groups such as manufacturers EEF and petrochemicals behemoth INEOS believe that the tax should be scrapped - while on the other hand Energy giant's SSE and EDF argue that it must be kept or even increased (Gosden, 2016). With manufacturing being a major contributor to GHG emissions around the world (Martin et al., 2014) it is no surprise that large manufacturing companies believe the tax should be scrapped. There may be various reasons for a business wanting to increase the tax. One reason could be companies may be moving towards being greener already, and increased taxes would drive less green competitors out of the market as is the case with Scottish Power closing a large coal power station. 
The short run effects of such taxes should not be felt in final commodity prices, since these are determined in world markets. These changes in underlying prices provide two key incentives for producers - to change to more environmentally friendly production techniques and, or to switch resources to production of less environmentally harmful goods (Webster and Ayatakshi, 2013). Furthermore, taxing carbon can push firms to reduce energy consumption and associated costs through low-carbon technology innovation and installation, thus the company may become more competitive in the market (Wang et al., 2016).

\section{Are carbon taxes regressive or progressive?}

A progressive tax system is one which high earners pay more tax relative to their income. The debate about whether a carbon tax can be progressive is one which is not easy as a study by Dissou and Siddiqui (2013) show results strongly indicating "that the total impact of carbon taxes on inequality is indeterminate, as it is context-dependent. That impact may be negative, positive or nil." This means that the results of a carbon tax can vary between nations. There are progressive traits of the tax which have been outlined in previous literature, such as, introducing a carbon tax would allow for reductions in income, labour, or even other taxes (Cuevas and Haines, 2015). Previous research have shown that in Denmark, the CO2 and other environmental taxes serve as an effective measure in reducing emissions (Wier et al., 2005) and the possibility that a carbon tax will stimulate innovation and efficiency in the energy sector with positive economic results (Ekins, 2003). Both seem to present the idea that carbon tax is more of a progressive tax.

On the other hand, regressive taxes are taxes which hit lower income earners more significantly and is the opposite of progressive taxes. Tax regressively relative to income means that households with lower income pay a greater share than those with a higher income (Wier et al., 2005). A study by Hamilton and Cameron (1994) analysing the distributional effects of 
a carbon tax found that the consequences of a carbon tax are regressive. Similar studies by Wier et al. (2005) and Dinan and Rogers (2002) find similar results for Denmark and the Netherlands, respectively. Dissou and Siddiqui (2013), Kerkhof et al. (2008), and Shammin and Bullard (2009) further confirm these results for the U.S. economy.

It is demonstrated that $\mathrm{CO} 2$ taxes imposed on households as well as industry do tend to be regressive and therefore have undesirable distributional effects. This holds especially true for taxes imposed directly on households (Wier et al. 2005).

\section{Methods}

This study uses both quantitative and qualitative methods. The first method of research is a survey conducted with accounting professionals in Scotland after a review of the current literature on carbon tax and climate change. The surveys are distributed online via email targeting professional accountants. Doing this will allow for a better quality of data from the survey as professional opinions are stronger than non-professionals. Following Elamer et al., (2019), a two-stage process was employed to obtain access to participants. First, the accounting firms were contacted via email or face-to-face and questioned to participate in our research. It was difficult to convince accountants and auditors; especially auditors working in the big offices to answer the questionnaire immediately or within the desired time frame due to work pressure. The snowballing method was then employed to additional participants where existing contacts were invited to identify other potential contacts who might be interested to participate in the present study. Second, new contacts were created through LinkedIn and colleagues and they were then requested to complete the questionnaire. This led to a final sample of 45 participants.

The second method of research is a formal interview which was conducted face to face with a regional finance director of an energy producing business, which is one of the companies 
in the Scotland most affected by the carbon tax. The interview looked to address the issues of a carbon tax in relation to the company and the closing of facilities in Scotland, it will also be used to gain an understanding of how an energy business is dealing with the switch to renewables. There will be an opportunity to get a perception on attitudes towards carbon taxes. The interview will cover how the company is battling the huge carbon tax bills with the implication of new energy efficient equipment.

As Table 1 shows, the survey was made available online to professional accountants. A total of 45 surveys were completed. This amount of responses is well beyond those published in the past year by accounting scholars, including Duff $(2016,2017)$ who published research with less than 30 professional respondents. All in all, the study's main sources of data are (1) a 2018 survey distributed to 45 accounting professionals in Scotland and a formal interview with a regional finance director of an energy producing company.

\section{Findings and Discussion}

The descriptive statistics representing the participant's socio-economic characteristics are presented in Table 1. The statistics firmly add to Duff $(2016,2017)$, which focus on professionals, with $89 \%$ still working in a professional environment, the other five respondents consider themselves retired. However, interestingly, none of the 5 retired professionals fall in to the lower income brackets and therefore their influence and contribution to the study is critical. With an average mean of 3.02 the majority of respondents are represented in the higher income categories.

Among the respondents, there is nearly an equal split of male to female, represented by $53 \%$ to $47 \%$. In terms of age, the majority of respondents are categorised in the $26-45$ years old working category. However, with a mean of 2.93 the sample is fairly representative of all ages and the data analysis is able to encapsulate the views of professional males and females 
across a variety differing ages and income brackets. Respondents were from the Provincial CDC (18.8\%), Prefecture-level city CDCs (66.9\%) and District/County level CDCs (14.3\%), respectively.

\section{INSERT TABLE 1 ABOUT HERE}

At the outset, participants were asked about their level of understanding regarding carbon taxes. This was asked to give a clearer understanding on public knowledge. The result shows that most of the accountants have a good understanding of carbon taxes and how they work as shown in Table 2 with a mean of 3.64. One comment from the survey said that a carbon $\operatorname{tax}$

"Encourages generators to consider investing in cleaner technologies ahead of traditional fossil fuels which incur higher emission taxes". This agrees with what was discussed in recent literature. Murray (2016) argues that carbon initiatives such as carbon taxes on GHG offer motivations to improve energy efficiency and resource productivity. This inturn, provides Scottish producers a sustainable competitive advantage in a globe where fossil fuel charges could increase because shortage and carbon reduction policies are possible to become more common.

The interview conducted with the energy company financial director provided a different outlook, rather than energy companies switching over to greener energy production techniques to avoid paying carbon tax bills, he explains that all the carbon tax has done is “accelerate the demise of coal plants" (Financial Director A 2017) as they have become too "uneconomical to run" (Financial Director A 2017) thus forcing the company to close power stations which has led to job loss. It can be said that the carbon tax has failed in motivating companies to move from fossil fuels to completely renewable sources because rather than move 
away from fossil fuels, the Financial Director said they simply moved from the heavily pollutant and now expensive coal to "gas fired power stations" (Financial Director A, 2017). One comment suggests that the worst emitters are not actually paying the bill and so are not going to switch to green energy if they just get customers to pay the bill. The issues with customer bills will be discussed in the following section.

In relation to professional accountants' acceptability of carbon taxes, secondly, Fig 1 suggests that, interestingly, there is no definitive evidence over who should pay carbon taxes. However, Table 2 shows that most of respondents believe that anyone producing carbon emissions should pay carbon taxes with a mean of 3.05 .

\section{INSERT FIGURE 1 ABOUT HERE}

The logical argument, that the polluters are the entities/people who should be taxed (Marron \& Toder, 2014) is prevalent here with $40 \%$ in agreement. At the other side of the spectrum, a significantly high proportion of professionals believe that everyone should be taxed, however would this create more austerity within lower social classes in society? Large companies are considered the main culprits (Beck, Rivers, Wigle, \& Yonezawa, 2015; Martin, De Preux, \& Wagner, 2014; Mathur \& Morris, 2014). However, just under 33\% of the sample believe they should be paying: with a sample solely inclusive of professionals, some could argue that a self-interest shines through here in respect, that because they are larger they can pay deflecting any potential cash outflow away from the individual.

\section{INSERT TABLE 2 ABOUT HERE}

Thirdly, despite there being strong agreement that individual can assist in the reduction of carbon emissions with $60 \%$ in agreement, the respondents place the majority of blame and 
responsibly on energy companies. Ultimately, energy companies are those who can impose higher non-tax related charges and therefore offer more efficient and effective mechanisms in aide of achieving a greener planet. However many would question their desire to do this to customers. Therefore, it can be argued that there responsibility lies in finding greener alternatives at a price that reflects the current market rates, allowing for the phasing out of carbon pollution.

Fourthly, the argument over who should pay, presents some clear conclusions. A strong majority believe that energy companies should pay the bill themselves and that the cost should not affect consumer prices with many quoting that energy companies make large enough profits so they should pay the bill. Some commentary from the survey which relates to "what would be considered an acceptable rise in price' includes:

“£0 as energy companies make enough profit" and "Don't think this figure should be increased as energy payments are high enough and these companies make huge profits already". These comments from consumers tie in with what was previously highlighted in the literature where it was said that "The short run effects of such taxes should not be felt in final good prices" (Webster and Ayatakshi 2013).

Approximately $60 \%$ arguing that a $£ 30$ increase per person is unacceptable and $52 \%$ saying they are not willing to pay any more, there is clear opposition and future consequences if such a policy was introduced. Interesting, out of the $33 \%$ who would be willing to pay in excess of $£ 30$, only 5 of these people come from the high earner $>£ 60,000$ as shown in Fig 3 , implying there is a somewhat negative relationship, with paying for what you do not believe you have caused 
It is also evident that some who disagree or strongly disagree that $£ 30$ is not fair (60\%), would be willing to contribute to carbon taxes. It can therefore be evaluated, that despite the view of it being unjust, there would be willing to make an arbitrary payment to achieve greater good in an ever changing environment. The wide standard deviation of 24.76 and mean of 17.60 confirm this view. Considering the views across the sample, there is again an unclear conclusion regarding the justification of any increase. With $70 \%$ believing that polluters and large companies should pay and not individuals there is evidence that this approach supported by professionals.

However, during the interview with the Financial Director they defend the price rises attributed with the carbon tax. They quote that, "people think they should get their gas and electricity for nothing. That's just the mindset of people in the UK" (Financial Director A 2017). The Financial Director cites that $15-20$ years ago, utility bills were not as big a part of monthly household bills as they are now and recognise that nowadays for a lot of people it is tough. However, their reasons for price rises, they feel, are genuine and justifiable. "Your basic energy is more expensive now... because you need to go through different renewables or sort of gas fired power stations." (Financial Director A 2017). Which is just a product of carbon taxes implications on the price of coal.

Wang et al (2016) debate the fact that carbon tax burdens will affect the poor more heavily by mentioning that poor people spend a larger portion of their income to meet their basic needs such as heating and electricity. The data could be interpreted to attest to these claims by showing how lower income households disagree more with the rise in utility prices than those on higher incomes. Energy companies, although they pass the cost of the carbon tax bill to all households, are progressive in the way that they treat the nation's poorer demographic. The ECO scheme was put in place for energy companies to meet a government set amount of carbon savings per year, Carbon savings are essentially saving the amount of 
$\mathrm{CO} 2$ expelled into the atmosphere. The only way that this can be achieved is through the companies directly paying for and installing new energy efficient items for people's home such as; "boilers home insulation, cavity wall insulation, solid wall insulation are the main ones" (Financial Director A 2017). These installations are only done in certain areas, rural areas mainly. However, the Financial Director comments that "poorer people will benefit from the ECO scheme if they apply" (Financial Director A 2017) as the company 'means test' people for new boiler installations and those who are on benefits are be entitled to a new boiler if they apply through the ECO scheme. These initiatives will make their homes more energy efficient and thus lower their household energy bills.

The idea that uncertainties (in price rises) can lead to widespread rejection from the public was put forward by Murray (2016) which is evident through the results of the survey as most tend to reject the price rise and most probably did not realise the reason for the price rise. A respondent commented within the survey, "I understand the impact of Carbon Taxes on consumer bills. I'm not sure that the general public have the same understanding”. Which ties in well the idea that the public were uncertain of the price rises and therefore could cause them to reject the premise behind it.

What appears to be most surprising is that of the 13 responses who were willing to pay above the $£ 30$ and pay either $£ 50$ or $£ 100$, not one of them was one of the highest income bracket of earning $£ 60,000+$. Many of the participants in the $£ 60,000+$ income bracket said that the $£ 30$ increase was "reasonable" and so opted to not increase or decrease the amount. Nonetheless some chose $£ 0$, in fact $33 \%$ of the participants who chose $£ 0$ were in the highest income bracket. Reasons they gave were to do with energy companies making enough profit while others said they should be already be providing green energy. Some comments in the survey on this issue from participants are; 
"Renewables are fast becoming the go to source for energy production. Instead of investing and exploring for sources of oil, they should focus on providing green energy. It is down to the companies to ensure they can cover the expense, not expect their customers to foot the bill." and, "while I completely agree with the need to reduce carbon emissions \& the impact on climate, these companies make huge profits already and it should be part of their ethos \& best practise already to looking at ways to make the process more efficient thereby reducing carbon emissions \& ultimately the cost to customers. ".

Although the higher income brackets agreed with the price rises more it was surprising to find that they were less inclined to a further increase in bill rises compared to lower income households.

Fifthly, as a responsible society, Fig 3 shows that there is acceptance that we can all do more to reduce emissions. As a population, we consider ourselves to be over reliant on our cars and need to consider alternatives whilst carefully monitoring energy use to try and assist in reducing carbon emissions globally. Literature suggests car emissions (Gössling, Scott, \& Hall, 2015) and this ties in with the study, where general acceptance of this ever increasing problem is apparent. Furthermore, comments from the Financial Director tie in with the idea of electric cars being used, he states that "if you were getting an electric vehicle... save a lot on petrol and diesel... To buy one now is... probably double what a normal car would be. Overtime you would hope that electric vehicles would be the norm" (Financial Director A, 2017). In the future the price of electric cars should decline due to technological advancements which will give common citizens access to a way of lowering their emissions but until then there is still a reliance on fossil fuelled powered vehicles.

Monitoring energy use at home, or in a business, was the second most popular answer behind using the car less and walking. This is perhaps the more realistic for most people to 
achieve and could potentially have a knock-on effect that could eventually lower utility prices. For example, if people were to use less energy at home then energy companies would not need to create as much energy thus causing them to have less carbon emissions which would lower their carbon tax bill and they could pass the savings back to the consumer. Within the interview with the Financial Director, there was a discussion about 'smart meters'. Smart meters are to be a replacement for the standard methods of gas and electric measurements currently in place, being that someone would come out and take a reading from your 2 household meters. For the companies, it allows for them to produce more accurate bills and for the consumer, it allows them to monitor their energy use in a much easier and more efficient way. Again, this is another massive expense for energy companies to install one in each customer's home and some people might not be interested in having one due to the hassle of installation (Financial Director A, 2017).

What they provide however is a means for customers to "control their energy and reduce their bill and just use less of the product" (Financial Director A, 2017) this could help lower every person's individual carbon footprint from the ground up. More people being aware of the smart meters and allowing them to be installed in their homes could potentially benefit final goods prices and have some sort of environmental impact.

Many people admit to wasting energy in the comments of the survey with some comments being; "Using my gas and electric more wisely to reduce the amount I need." and "Do not use your gas or electricity when it is not essential i.e. Heating in summer." People acknowledge how wasteful they are and so the smart meters could be put to great use and allow for wiser energy consumption habits through making users aware of the energy they are using immediately. This wasteful behaviour is backed up by a comment from the Financial Director where they claim that "people will be leaving their gas and electricity on when they're not in 
the house. Which is the equivalent of me taking out $£ 10$ and setting it on fire. It's just wasting energy." (Financial Director A, 2017)

Wasting energy could be applied to the population wholly as nobody can safely say they do not waste energy of some kind at home, even if it is as little as leaving a light on. One comment in particular from a respondent who works in the energy sector with a great understanding of carbon taxes talks about a need for a change in public behaviour which is more than likely what is needed, he said that "Changes in public behaviour (this creates the demand for energy) are required. Reduction on use of motor cars and general consumption of energy is key. Also, small scale local generation (e.g. PV or wind) supported by improvements in battery technology will also be key in the future." (See appendix 8 for comments).

Somewhat surprisingly, $8 \%$ were unsure of how they could reduce their carbon emissions and therefore there is a need for a better understanding through education to make people aware of how to lower their carbon footprint. Utilisation of the smart meters would help to ensure the public have a way of lowering their emissions by real time monitoring of electricity usage.

\section{INSERT FIGURE 3 ABOUT HERE}

Finally, the way forward is evident, not only from the survey but from what happens in reality. As a nation, collectively, we need to find greener mechanisms. The evolution of a greener society has been evident for centuries, the reduction in coal output, combined with the reduction in nuclear power demonstrates that currently we are achieving the views of the majority. However, what is transparent is that there are some who value other social welfare benefits such as a free education and a NHS more than carbon tax as shown in Fig4. It could be argued that these views are more short term focused individuals, who have somewhat 
accepted that green power is too far in the distant and it would be more beneficial to solve todays problems rather than tomorrows.

An important point as highlighted by the Financial Director during the interview in regards to renewables is the cost association. Wind farms are the greatest clean energy investment for energy companies, both on shore and off shore. As mentioned in the interview “it's not like (power station name removed) where you need to buy lots of coal to fire up the turbines to make it work to create electricity, once it's up there it's just whirling round so there's a big huge capital investment to begin with but then you could actually get a good return over several years, they can be for 20/25 years" (Financial Director A 2017). Interestingly, Martin, de Preux and Wagner, (2014) commented on how some energy companies such as EDF want the carbon tax increased as they want their competitors to lose profits due to the carbon tax forcing the closure of coal fired power stations and ultimately forcing companies to heavily invest in wind farms and other renewables.

Although there are always cheaper ways to do produce energy, there are many other influencing factors that are out with a companies' control, for example, the Financial Director mentions Brexit as an influencing factor and how lots of materials needed to build a windfarm are imported from the EU and with Brexit's impact on the Euro they have seen the cost of materials go up. Hydro stations are another good alternative, however there are very few in operation and they do not provide enough energy to cover full cities on their own. They are relatively clean though. (Financial Director A, 2017)

A point worth mentioning in relation to the wind and wave energy is through the amount of revenue this could potentially then create for Scotland while also creating employment opportunities in a growing business sector. "It [Scotland] has natural energy resources the envy of Europe, with $25 \%$ of the EU's offshore wind and tidal power potential and $10 \%$ of its 
wave power potential, and some 90\% of the UK's hydro capacity." (Carrell, 2014 pg1). Therefore, proper investment from the Scottish government within this sector should be viewed as a priority. Of all those who would like to see investment in green energy initiatives $64 \%$ are accountants earning over $£ 60,000$ per year with males making $50 \%$ of that and females making up $14 \%$. In contrast when it came to help those less fortunate and the nation's more vulnerable, Females earning between $£ 20,000-£ 40,000$ made up $66 \%$ of all those responses. This difference could be due to females being more caring and empathetic than males in general, this could be backed up by saying that females outnumbered males in both investment in the NHS/Health and education.

Improvements to public transport can have a direct positive impact on energy consumption and was the second most popular choice, improving public transport to be more efficient would result in less cars on the road and therefore less pollution. With $60 \%$ of Americans saying they would support a carbon tax if the revenue was put to good use (Spross, 2014), perhaps similar studies could be done in Scotland to allow for comparison.

\section{INSERT FIGURE 4 ABOUT HERE}

From the literature, it said that a carbon policy can be progressive if the rich are affected more adversely rather than welfare reduction being felt in all households (Dissou and Saddiqui, 2013). This appears to hold untrue as the Financial Director explains "Ultimately consumers pay for it and they're not really having an input" (Financial Director A, 2017). An alternative idea suggested would be to add a couple of pence onto everyone's income tax bill rather the cost going through an energy company's profit and loss which would not only pay for the tax but stop utility prices rising and save energy companies grief in the process while also improving their profits. (Financial Director A, 2017). 


\section{Conclusion and Policy Implications}

The increasing empirical perception of public stances toward carbon taxes can assist policymakers and regulators to design carbon taxes in a way that is more acceptable for society as a whole. This paper aimed to gain an understanding of the accounting society's acceptability of carbon taxes. Society can be affected both positively and negatively from a carbon tax as shown throughout this paper, positively through aspects such as, the fiscal revenue governments receive and reinvest into society to help with issues surrounding climate change. Also, the positive environmental impact which could be brought on by energy companies changing their sources of energy production to renewables so they can cut their carbon tax bill. The negative aspects associated with the carbon tax were to do with how they ultimately impact consumers utility bills through price rises which were thought to affect the worst off in society Finally, the overall effectiveness of carbon taxes was explored to see if they do lead to a reduction in emissions with an emphasis on how society feel they can help in reducing their emissions as opposed to facing the burdens that come with carbon taxes.

The accounting society's acceptability of carbon taxes varies depending on the individuals' level of understanding of the tax and their understanding of how it can affect society. Key reasons for the negative views were attributed to who ends up paying the carbon tax bill, which was found to be the end users of the energy i.e. the customers. Energy companies passing through the cost to end customers was a big concern for many with the idea that energy companies should not pass through the cost as they make enough profits, so they should pay it themselves being an important factor in forming opinion. Rising utility bills was found to not be solely based on the carbon tax but included other schemes such as the ECO scheme and renewable obligation put on energy companies from government. All these factors were found to have a negative impact for consumer bills. 
However, once the respondents of the survey were presented with new, more positive, information about how they can be affected by a carbon tax policy many opinions were changed to a more positive one as highlighted in the survey. Positive information that was presented related to how carbon taxes can have positive implications for the environment by providing a means for reducing levels of carbon dioxide in the atmosphere which can help slow down climate change and provide a better world for future generations. This coupled with information from the government on the appropriate use of carbon revenues could create a positive opinion for carbon taxes as many changed their opinion when presented with alternative facts. Overall, the positive aspects of the carbon tax outweighed the negative for many which could somewhat lead to the acknowledgement of carbon taxes being a success.

Carbon taxes can affect an energy producing business greatly as energy companies in Scotland relied heavily on the heavy pollutant coal until recently. Introducing the carbon tax was a way in which the government wanted these companies to move away from the reliance on fossil fuels and 'force' them to switch to greener energy production. It was found the carbon tax alone does not actually impact on the reliance on fossil fuels, coal is an exception, however, gas fired power stations and oil driven cars are still a popular choice for producing energy and transportation respectively. Until renewable energy becomes cheaper fossil fuels will continue to be a dominant fuel source in Scotland. Energy companies find the tax unnecessary as all it is effectively is a tax on the end user which must go through their profit and loss to a negative effect.

Overall, the reality on the effectiveness of carbon taxes at reducing carbon emissions is not as great as the government would perhaps have liked them to be. Although coal is no longer widely used there are still many other areas that should be addressed in relation to $\mathrm{CO} 2$ emissions. A change in the public's behaviour regarding energy use is recommended as it is believed that this would have a greater impact on lowering emissions than a tax would. If 
households in the UK made greater effort to monitor their energy use by utilising the newly available smart meters, using their car less or switch to an electric car, albeit they are currently expensive to buy, in time we would see a reduction in $\mathrm{CO} 2$ that would eliminate the need for a carbon tax and save the need for energy companies to put up their tariffs while still providing positive changes to the environment.

Carbon taxes are mostly seen by professionals to be poorly implemented taxes that affect everyone, while they can help in reducing in $\mathrm{CO} 2$ levels to some extent the issues that surround climate change are much wider. Going forward, it would be recommended for further research to be conducted on how public behaviour in relation to energy use can be changed and if so how this could be brought about. If carbon taxes are charged through to customers' bills and energy companies do not switch over to renewables as much as governments and green energy promoters hope then the overall effectiveness of the tax is open to question, however if their goal was to move energy production away from coal then they could be viewed as being effective. In addition the acceptability of carbon taxes is significantly affected by the perceived tax effectiveness, government credibility, by the information offered on climate change, and by the level to which public people are willing to pay. The carbon taxes will be rejected if the aim of the tax is not obvious and broadly clarified before it is applied, and if its predictable influences, both on the environment and on the economy, are not sufficiently pronounced. On condition that a proper information campaign is prepared, the expected preliminary reluctance to accept carbon taxes might weaken over time.

Thus, future research could investigate the wider publics and accountants, behaviour and understanding of carbon taxes following its introduction and evolution in society. Performing in-depth interviews with accounting firms regarding climate change and taxation would enrich current research, as would speaking to some of the specialised energy and taxations teams that are emerging as accountants continue to provide clients with the 
information they require. Another limitation of the research is the small sample size. For this reason, attention should be given when expanding the findings obtained to the overall population of UK citizens. However, the findings in this paper are beneficial as a preliminary point for future experiments, since to the best of our knowledge, no other study has been carried out on this topic in Scotland or/and UK. It would be recommended that world governments continue their efforts in making the environment a safer place for future generations. Therefore, proper investment from the Scottish government within this sector should be viewed as a priority. Also, a different approach, rather a carbon tax or EUETS, could be researched that involved providing cheaper renewable energy sources for households. With an overwhelming majority of the respondents believing that more can be done to fight global warming and climate change it would be recommended that world governments continue their efforts in making the environment a safer place for future generations. Therefore, proper investment from the Scottish government within this sector should be viewed as a priority. 


\section{References}

Adhikariparajul, M., Hassan, A., Fletcher, M., \& Elamer, A. A. (2019). Integrated reporting in UK higher education institutions. Sustainability Accounting, Management and Policy Journal, Forthcoming. https://doi.org/10.1108/SAMPJ-03-2018-0093

Alshbili, I., Elamer, A. A., \& Beddewela, E. (2019). Ownership types, corporate governance and corporate social responsibility disclosures: Empirical evidence from a developing country. Accounting Research Journal, Forthcoming. https://doi.org/10.1108/ARJ-03-2018-0060.

Andersen, M.S. and Ekins, P. (2009). Carbon-Energy Taxation: Lessons from Europe. Oxford Scholarship Online pp1.

Baranzini, A., \& Carattini, S. (2017). Effectiveness, earmarking and labeling: testing the acceptability of carbon taxes with survey data. Environmental Economics and Policy Studies, 19(1), 197-227.

Beck, M., Rivers, N., Wigle, R., \& Yonezawa, H. (2015). Carbon tax and revenue recycling: Impacts on households in British Columbia. Resource and Energy Economics, 41, 40-69.

Böttcher, C. F., \& Müller, M. (2015). Drivers, Practices and Outcomes of Low-carbon Operations: Approaches of German Automotive Suppliers to Cutting Carbon Emissions. Business Strategy and the Environment, 24(6), 477-498.

Bounds, A. (2015). Coal industry blames carbon taxes as Scottish power plant closes. [Online] Available URL: https://www.ft.com/content/801e120e-45c4-11e5-b3b2-1672f710807b [Accessed 12 December 2016].

Brannlund, R., \& Persson, L. (2012). To tax, or not to tax: preferences for climate policy attributes. Climate Policy, 12(6), 704-721.

Bredin, D. and Muckley, C. (2011). An emerging equilibrium in the EU emissions trading scheme. Energy Economics. 33(2), 353-362.

Carattini, S., Kallbekken, S., \& Orlov, A. (2019, January 16). How to win public support for a global carbon tax. Nature, Vol. 565, pp. 289-291.

Carl, J. and Fedor, D. (2016). Tracking global carbon revenues: A survey of carbon taxes versus cap-and-trade in the real world. Energy Policy. 96, 50-77.

Carrell, S. (2014). Scottish power: rich in green energy but light on green revenues. [Online] Available URL: https://www.theguardian.com/politics/scottish-independence-blog/2014/apr/08/scotland-scottish-greenenergy-taxes [Accessed on 28 January 2017].

CCP. (2018). Climate change plan the third report on proposals and policies 2018-2032. Retrieved from https://www.gov.scot/publications/scottish-governments-climate-change-plan-third-report-proposalspolicies-2018/pages/1/

Chen, C. M., \& Montes-Sancho, M. J. (2017). Do Perceived Operational Impacts Affect the Portfolio of Carbon-Abatement Technologies?. Corporate Social Responsibility and Environmental Management. 24, 235-248

Cherry, T. L., Kallbekken, S., \& Kroll, S. (2012). The acceptability of efficiency-enhancing environmental taxes, subsidies and regulation: An experimental investigation. Environmental Science \& Policy, 16, 90-96.

Clinch, P., \& Beuermann, C. (2006). Social and political responses to ecological tax reform in Europe: an introduction to the special issue. Energy Policy, 34(8), 895-904.

Crowley, K. (2017). Up and down with climate politics 2013-2016: the repeal of carbon pricing in Australia. Wiley Interdisciplinary Reviews: Climate Change, 8(3), e458.

Cuevas, S. and Haines, A. (2015). Health benefits of a carbon tax. The Lancet. 387(10013), 7-9.

de Groot, J. I. M., \& Schuitema, G. (2012). How to make the unpopular popular? Policy characteristics, social norms and the acceptability of environmental policies. Environmental Science \& Policy, 19-20, 100 107.

Dickie, M (2015) Scottish power to close Longannet plant due to taxes and charges. [Online] Available URL: https://www.ft.com/content/bbd14aaa-458d-11e5-b3b2-1672f710807b [Accessed on 16 December 2016]

Dissou, Y. and Siddiqui, S.S. (2014). Can carbon taxes be progressive? Energy Economics. 42, 88-100.

Drews, S., \& van den Bergh, J. C. J. M. (2016). What explains public support for climate policies? A review of empirical and experimental studies. Climate Policy, 16(7), 855-876.

Duff, A. (2016). Corporate social responsibility reporting in professional accounting firms. The British accounting review, 48(1), 74-86.

Duff, A. (2017). Social mobility and Fair Access to the accountancy profession in the UK: Evidence from Big Four and mid-tier firms. Accounting, Auditing \& Accountability Journal, 30(5), 1082-1110.

Economic and Social Research Council (ESRC). (2000) Opportunities for change. Response to the consultation paper: A revised UK strategy for sustainable development. Parliament: London. https://publications.parliament.uk/pa/cm199900/cmselect/cmenvaud/175/175m12.htm. 
Ekins, P. (1994). The impact of carbon taxation on the UK economy. Energy Policy. 22(7), 571-579.

Elmagrhi, M. H., Ntim, C. G., Elamer, A. A., \& Zhang, Q. (2019). A study of environmental policies and regulations, governance structures and environmental performance: The role of female directors. Business Strategy and the Environment, 28(1), 206-220.

Evangelinos, K., Nikolaou, I., \& Leal Filho, W. (2015). The effects of climate change policy on the business community: a corporate environmental accounting perspective. Corporate Social Responsibility and Environmental Management, 22(5), 257-270.

Eweje, G. (2011). A shift in corporate practice? Facilitating sustainability strategy in companies. Corporate Social Responsibility and Environmental Management, 18(3), 125-136.

Gerged, A. M., Cowton, C. J., \& Beddewela, E. S. (2018). Towards Sustainable Development in the Arab Middle East and North Africa Region: A Longitudinal Analysis of Environmental Disclosure in Corporate Annual Reports. Business Strategy and the Environment, 27(4), 572-587.

Gosden, . (2016) Power politics: industry battle as Chancellor to rule on carbon tax. [Online] Available URL: http://www.telegraph.co.uk/business/2016/10/15/power-politics-industry-battle-as-chancellor-to-ruleon-carbon-t/ [Accessed 14 December 2016].

Gosden, E. (2016). Phase out UK carbon tax to avoid importing dirt power from Europe, says think tank. [Online] Available URL: http://www.telegraph.co.uk/business/2016/11/18/phase-out-uk-carbon-tax-toavoid-importing-dirty-power-from-euro/ [Accessed 13 December 2016].

Gosden, E. (2016). Treasury faces row over future of carbon tax. [Online] Available URL: http://www.telegraph.co.uk/finance/newsbysector/energy/12116628/Treasury-faces-row-over-futureof-carbon-tax.html [Accessed 10 December 2016].

Gössling, S., Scott, D., \& Hall, C. M. (2015). Inter-market variability in CO2 emission-intensities in tourism: Implications for destination marketing and carbon management. Tourism Management, 46, 203-212.

Guo, Z., Zhang, X., Zheng, Y., \& Rao, R. (2014). Exploring the impacts of a carbon tax on the Chinese economy using a CGE model with a detailed disaggregation of energy sectors. Energy Economics, 45, 455-462.

Hansford, A., Hasseldine, J., \& Woodward, T. (2004). The UK climate change levy: good intentions but potentially damaging to business. Corporate Social Responsibility and Environmental Management, 11(4), 196-210.

Harrison, K. (2010). The Comparative Politics of Carbon Taxation. Annual Review of Law and Social Science, 6(1), 507-529.

Harrison, K., \& Peet, C. (2012). Historical Legacies and Policy Reform: Diverse Regional Reactions to British Columbia's Carbon Tax. BC Studies: The British Columbian Quarterly, (173), 97-122.

Horton, M. and El-Ganainy, A. (2009). What is fiscal policy. Finance and Development. 46(2), 55.

Hsu, S. (2012) The Case for a Carbon Tax. Island Press/Center for Resource Economics, 1-11.

Hwang, J. A., \& Kim, Y. (2017). Effects of Environmental Regulations on Trade Flow in Manufacturing Sectors: Comparison of Static and Dynamic Effects of Environmental Regulations. Business Strategy and the Environment. 26, 688-706.

Jacobs, B. and de Mooij, R (2015). Pigou meets Mirrlees: On the relevance of tax distortions for the second-best Pigouvian tax. Journal of Environmental Economics and Management. 71, 90-108.

Jagers, S. C., Martinsson, J., \& Matti, S. (2019). The impact of compensatory measures on public support for carbon taxation: an experimental study in Sweden. Climate Policy, 19(2), 147-160.

Kallbekken, S., \& Aasen, M. (2010). The demand for earmarking: Results from a focus group study. Ecological Economics, 69(11), 2183-2190.

Kallbekken, S., \& Sælen, H. (2011). Public acceptance for environmental taxes: Self-interest, environmental and distributional concerns. Energy Policy, 39(5), 2966-2973.

Li, J., \& Lin, B. (2016). Inter-factor/inter-fuel substitution, carbon intensity, and energy-related CO 2 reduction: empirical evidence from China. Energy Economics, 56, 483-494.

Maibach, E. W., Kreslake, J. M., Roser-Renouf, C., Rosenthal, S., Feinberg, G., \& Leiserowitz, A. A. (2015). Do Americans Understand That Global Warming Is Harmful to Human Health? Evidence From a National Survey. Annals of Global Health, 81(3), 396-409.

Marron, D. B., \& Toder, E. T. (2014). Tax policy issues in designing a carbon tax. The American Economic Review, 104(5), 563-568.

Martin, N. J., \& Rice, J. L. (2014). Influencing clean energy laws: an analysis of business stakeholder engagement. Business Strategy and the Environment, 23(7), 447-460.

Martin, R. de Preux, L.B. and Wagner, U.J. (2014). The impact of a carbon tax on manufacturing: Evidence from microdata. Journal of Public Economics. 117, 1-14.

Mathur, A., \& Morris, A. C. (2014). Distributional effects of a carbon tax in broader US fiscal reform. Energy Policy, 66, 326-334. 
Metcalf, G. and Weisbach, D. (2009). The Design of a Carbon Tax. Harvard Environmental Law Review. 33, 499-556.

Murray, B., \& Rivers, N. (2015). British Columbia's revenue-neutral carbon tax: A review of the latest "grand experiment" in environmental policy. Energy Policy, 86, 674-683.

Murray, J. (2016). UK-wide carbon tax would have 'little impact' on consumers. [Online]. Available URL: https://www.theguardian.com/environment/2016/jan/11/uk-wide-carbon-tax-would-have-little-impacton-consumers-study-finds [Accessed on 5 December 2016].

Rabe, B. G., \& Borick, C. P. (2012). Carbon Taxation and Policy Labeling: Experience from American States and Canadian Provinces. Review of Policy Research, 29(3), 358-382.

Robson, A. (2014). Australia's Carbon Tax: An Economic Evaluation. Economic Affairs. 34(1), 35-45.

Sælen, H., \& Kallbekken, S. (2011). A choice experiment on fuel taxation and earmarking in Norway. Ecological Economics, 70(11), 2181-2190.

Schleich, J., Schwirplies, C., \& Ziegler, A. (2018). Do perceptions of international climate policy stimulate or discourage voluntary climate protection activities? A study of German and US households. Climate Policy, 18(5), 568-580.

Shwom, R., Bidwell, D., Dan, A., \& Dietz, T. (2010). Understanding U.S. public support for domestic climate change policies. Global Environmental Change, 20(3), 472-482.

Smith, C. (2012). Definition of environmental tax published. [Online] Available URL: https://www.gov.uk/government/news/definition-of-environmental-tax-published [Accessed 10 December 2016].

Spross, J. (2014). 60 percent of Americans support a carbon tax when the revenues are put to good use. [Online] Available URL: https://thinkprogress.org/60-percent-of-americans-support-a-carbon-taxwhen-the-revenues-are-put-to-good-use-f208ce704493\#.hxkeukgc7 [Accessed on 20 February 2017].

Varma, A. (2002). UK's climate change levy: cost effectiveness, competitiveness and environmental impacts. Energy Policy. 31(1), 51-61.

Wang, Q. Hubacek, K. Feng, K. Wei, Y. and Liang, Q. (2016). Distributional effects of carbon taxation. Applied Energy. 184, 1123-1131.

Wang, X. Li, J.F. and Zhang, Y.X. (2011). An analysis on the short-term sectoral competitiveness impact of carbon tax in China. Energy Policy. 39(7), 4144-4152.

Webster, A. and Ayatakshi, S. (2013). The effect of fossil energy and other environmental taxes on profit incentives for change in an open economy: Evidence from the UK. Energy Policy. 61, 1422-1431.

Webster, R. (2014). UK electricity mix in 2013: less gas, still lots of coal, but winds on the up. [Online] Available URL: https://www.carbonbrief.org/uk-electricity-mix-in-2013-less-gas-still-lots-of-coal-butwinds-on-the-up [Accessed on 17 December 2016].

Wier, M. Birr-Pedersen, K. Jacobsen, H.K. and Klok, J. (2005). Are Co2 taxes regressive? Evidence from the Danish experience. Ecological Economics. 52, 239-251.

Zhang, Z., Zhang, A., Wang, D., Li, A., \& Song, H. (2017). How to improve the performance of carbon tax in China?. Journal of Cleaner Production, 142, 2060-2072. 
Tables

Table 1: General Sample socio-economic characteristics

\begin{tabular}{llll}
\hline Variables & & No of respondents & Percentage (\%) \\
\hline Age & $16-25$ & 8 & 17.8 \\
& $26-35$ & 10 & 22.2 \\
& $36-45$ & 12 & 26.7 \\
& $46-55$ & 7 & 15.6 \\
& $>55$ & 8 & 17.8 \\
\hline Sex & Male & 24 & 53.3 \\
& Female & 21 & 46.7 \\
\hline Occupation & Professional - Working & 40 & 88.9 \\
& Retired & 5 & 11.1 \\
\hline Income & $0-20000$ & 4 & 8.9 \\
& $20001-40000$ & 10 & 22.2 \\
& $40001-60000$ & 12 & 26.7 \\
& $>60000$ & 19 & 42.2 \\
\hline
\end{tabular}


Table 2: professional accountants' acceptability of carbon taxes

\begin{tabular}{|l|l|l|l|l|l|}
\hline & Mean & Median & STD & Minimum & Maximum \\
\hline $\begin{array}{l}\text { Before this Survey, what was your } \\
\text { knowledge and understanding of carbon } \\
\text { taxes? }\end{array}$ & 3.64 & 3.00 & 0.98 & 1.00 & 4.00 \\
\hline Who should carbon taxes apply to? & 2.05 & 3.00 & 0.78 & 1.00 & 3.00 \\
\hline $\begin{array}{l}\text { Are individuals responsible for reducing } \\
\text { emissions? }\end{array}$ & 2.98 & 3.00 & 0.89 & 1.00 & 5.00 \\
\hline $\begin{array}{l}\text { Are energy companies responsible for } \\
\text { reducing emissions? }\end{array}$ & 3.02 & 3.00 & 0.99 & 1.00 & 5.00 \\
\hline $\begin{array}{l}\text { Do you think increase consumer prices } \\
\text { of gas and electric bills by £30 each is } \\
\text { fair? }\end{array}$ & 2.66 & 3.00 & 1.02 & 1.00 & 4.00 \\
\hline $\begin{array}{l}\text { How much extra are people willing to } \\
\text { pay? }\end{array}$ & 17.40 & 5.00 & 24.86 & 0.00 & 100.00 \\
\hline How does the public view carbon taxes? & 2.84 & 3.00 & .99 & 1.00 & 3.00 \\
\hline $\begin{array}{l}\text { Do you think more could be done to } \\
\text { fight global warming caused by burning } \\
\text { Fossils, such as coal and gas? }\end{array}$ & 3.00 & 3.00 & 1.13 & 1.00 & 5.00 \\
\hline
\end{tabular}




\section{Figures}

Fig 1. Who should carbon taxes apply to?

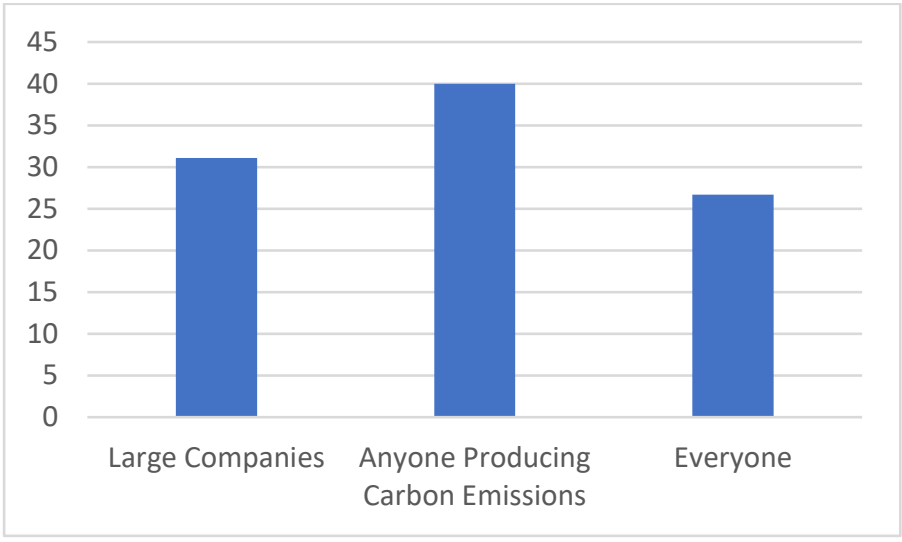


Fig 2. How much extra are accountants willing to pay?

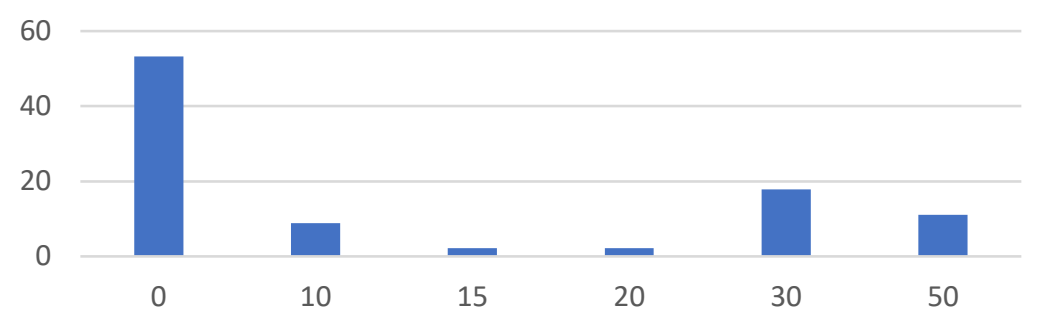


Fig 3. How accountants think they can reduce their emissions

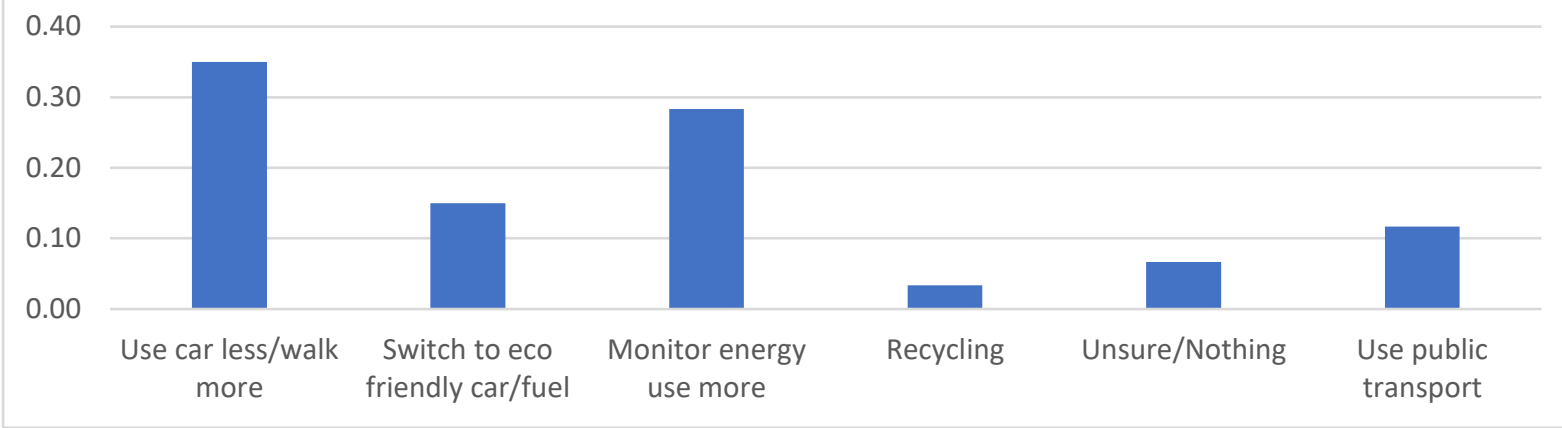


Fig 4. How the accountants think carbon tax revenues should be spent

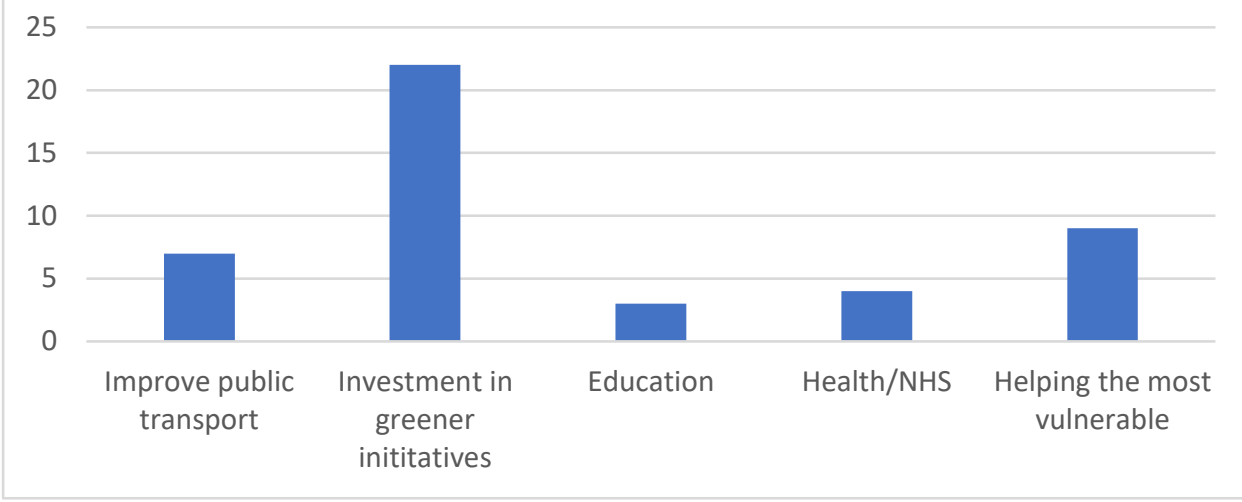

